\title{
Simulated Microgravity Promotes Horizontal Gene Transfer of Antimicrobial Resistance Genes between Bacterial Genera in the Absence of Antibiotic Selective Pressure
}

\author{
Camilla Urbaniak ${ }^{1,2}$, Tristan Grams ${ }^{1}$ (D), Christopher E. Mason ${ }^{3,4}$ (D) and Kasthuri Venkateswaran ${ }^{1, *}$ \\ 1 NASA Jet Propulsion Laboratory, California Institute of Technology, Pasadena, CA 91109, USA; \\ camilla.urbaniak@jpl.nasa.gov (C.U.); tgrams@ufl.edu (T.G.) \\ 2 ZIN Technologies Inc., Middleburg Heights, OH 44130, USA \\ 3 Department of Physiology and Biophysics, Weill Cornell Medicine, New York, NY 10065, USA; \\ chm2042@med.cornell.edu \\ 4 The World Quant Initiative for Quantitative Prediction, Weill Cornell Medicine, New York, NY 10065, USA \\ * Correspondence: kjvenkat@jpl.nasa.gov
}

\section{check for}

updates

Citation: Urbaniak, C.; Grams, T.; Mason, C.E.; Venkateswaran, K. Simulated Microgravity Promotes Horizontal Gene Transfer of

Antimicrobial Resistance Genes between Bacterial Genera in the Absence of Antibiotic Selective Pressure. Life 2021, 11, 960. https:/ / doi.org/10.3390/life11090960

Academic Editors: Fathi Karouia and Christopher H. House

Received: 24 August 2021

Accepted: 9 September 2021

Published: 13 September 2021

Publisher's Note: MDPI stays neutral with regard to jurisdictional claims in published maps and institutional affiliations.

Copyright: (c) 2021 by the authors. Licensee MDPI, Basel, Switzerland. This article is an open access article distributed under the terms and conditions of the Creative Commons Attribution (CC BY) license (https:/ / creativecommons.org/licenses/by/ $4.0 /)$.

\begin{abstract}
Bacteria are able to adapt and survive in harsh and changing environments through many mechanisms, with one of them being horizontal gene transfer (HGT). This process is one of the leading culprits in the spread of antimicrobial resistance (AMR) within bacterial communities and could pose a significant health threat to astronauts if they fell ill, especially on long-duration space missions. In order to better understand the degree of HGT activity that could occur in space, biosafety level-2, donor and recipient bacteria were co-cultured under simulated microgravity (SMG) on Earth with concomitant $1 \mathrm{G}$ controls. Two AMR genes, bla $a_{\mathrm{OXA}-500}$ and ISAba1, from the donor Acinetobacter pittii, were tracked in four recipient strains of Staphylococcus aureus (which did not harbor those genes) using polymerase chain reaction. All four S. aureus strains that were co-cultured with $A$. pittii under SMG had a significantly higher number of isolates that were now bla $a_{\text {OXA-500- }}$ and ISAba1-positive compared to growth at $1 \mathrm{G}$. The acquisition of these genes by the recipient induced a phenotypic change, as these isolates were now resistant to oxacillin, which they were previously susceptible to. This is a novel study, presenting, for the first time, increased HGT activity under SMG and the potential impact of the space environment in promoting increased gene dissemination within bacterial communities.
\end{abstract}

Keywords: horizontal gene transfer; simulated microgravity; high aspect ratio vessel (HARV); antimicrobial resistance; space environment; Staphylococcus aureus; Acinetobacter pittii

\section{Introduction}

Bacteria are able to adapt to a wide variety of conditions, as evidenced by their survival and growth in extreme environments, such as the arid Atacama desert [1], hypersaline salt mines and lakes [2,3], acidic rocks in the Yellowstone geothermal environment [4], and the multi-stressor environment of Antarctica [5]. Bacterial communities have also been found beyond the Earth's surface on the International Space Station (ISS), a low-gravity, high-radiation, hermetically sealed built environment [6]. The microbial communities characterized here consist of environmental organisms, human-associated commensal bacteria and biosafety level 2 (BSL-2) microbes, resistant to various antibiotics, and carrying numerous anti-microbial resistance genes [7-9]. This resistance could potentially pose a serious threat to astronauts if they fell ill, especially on long-duration space missions, as medical attention would not be readily available.

Horizontal gene transfer (HGT) is the movement of genetic material (i.e., DNA) between microorganisms through either transformation, conjugation or transduction, and is considered to be central to microbial evolution $[10,11]$. In dynamic mixed communities, 
either human or environmental, HGT between species may confer an overall fitness advantage to the community, as the acquisition of new traits in individual cells within that community allows them to better adapt to changing conditions [12-15]. In other cases, HGT may have an unfavorable effect if it leads to an excessive accumulation of genes, or a neutral one [16], if there is no impact on the fitness of the organism [16].

In a recent study comparing bacteria from two extreme built environments, one on Earth (Concordia Research Station in Antarctica) and one in space (International Space Station), a comparison between isolates of the same species showed that those from the International Space Station (ISS) had more mobile genetic elements within their genomes than those from Concordia [17]. In a follow-up analysis conducted by our group using the ISS resistome and microbiome data presented by Urbaniak et al. 2018 [7], we performed a series of correlation analyses to determine which antimicrobial resistance (AMR) genes were associated with which species. Interestingly, no statistically significant correlations were found. These data, coupled by the Concordia/ISS study, led us to hypothesize that the stressors of the ISS, specifically microgravity, promote enhanced HGT between organisms, compared to what would be observed on Earth.

To address this hypothesis, co-cultures between donor and recipient strains were grown under simulated microgravity (SMG) (which we used as a proxy for $\mu$ gravity conditions on the ISS) and normal gravity (1G), using the high-aspect-ratio vessel (HARV), with gene transfer tracked using polymerase chain reaction (PCR). The donor and recipient strains were Acinetobacter pittii (strain IIF1SW-P1) and Staphylococcus aureus (strains IF4SW, IIF6SW, IF7SW, IIF8SW), respectively. All strains were previously isolated from various locations on the ISS as part of the Microbial-1 Tracking study [8]. A. pittii IIF1SW-P1 was chosen as the donor, since it was previously shown by our group to be resistant to oxacillin and contained the chromosomally located bla OXA-500 gene within its genome [7], a betalactamase which alone can confer resistance to oxacillin [18]. The four S. aureus strains, IF4SW, IIF6SW, IF7SW, IIF8SW, were chosen as recipients because they were susceptible to oxacillin and harbored neither the $b l a_{\mathrm{OXA}-500}$ gene nor any other beta-lactamase genes [7]. The donor, A. pittii, harbored ISAba1, a transposable element that can jump between segments of the genome and, in some cases, can act as a promoter region for bla $a_{\mathrm{OXA}}$ genes, allowing for increased resistance to oxacillin and other beta-lactam antibiotics $[19,20]$. ISAba1 was not found in either of the recipient $S$. aureus strains. HGT ability was, therefore, tracked between A. pittii and S. aureus using the AMR genes, bla $\mathrm{OXA}-500$ and ISAba1.

\section{Methods}

\subsection{Co-Culture Experiments}

All strains examined in this study were cultivated from the ISS environment collected during Flight 2 (May 2015) as per the published protocol [8]. A. pittii strain, IIF1SWP1, was isolated at Location \#1, the Port panel of the Cupola. The Cupola is a small module devoted to the observation of operations outside the ISS, such as robotic activities, spacecraft approaches, and extravehicular activities. S. aureus strain IF4SW was isolated from Location \#4, the surface of the dining table. Even though the main function of the table was for dining, crew members also used the table for experimental work. S. aureus strain IIF6SW was cultured from the sample collected at Location \#6, a stowage rack where experimental materials were stored for long duration. S. aureus strain IF7SW was isolated from Location \#7, an overhead three-panel surface of the Materials Science Research Rack 1 , which is used for basic material research in the microgravity environment of the ISS. S. aureus strain IIF8SW was retrieved from the samples at Location \#8, an exterior aft wall of crew quarters. The crew quarters are a permanent personal space for crewmembers to sleep and perform personal recreation and communication, as well as provide on-orbit stowage of personal belongings.

Donor (A. pittii strain IIF1SW-P1) and recipient (S. aureus strains IF4SW-P1, IIF6SW-P1, IF7SW-P3, IIF8SW-P1) bacteria were streaked from $-80^{\circ} \mathrm{C}$ freezer stocks onto tryptic soy agar plates (Hardy Diagnostics, Santa Maria, CA, USA) and incubated overnight ( 16 h) 
at $37^{\circ} \mathrm{C}$. A single colony from each plate was added to $10 \mathrm{~mL}$ of tryptic soy broth (TSB) in a $50 \mathrm{~mL}$ Falcon tube for S. aureus, and $8 \mathrm{~mL}$ of TSB in a snap cap tube for A. pittii and grown overnight $(\sim 20 \mathrm{~h})$ in a shaking incubator at $85 \mathrm{rpm}$. A low speed was chosen, so as to not dislodge pili or flagella that could be used for HGT, but high enough that the bacteria did not settle out of culture over time. The overnight culture was centrifuged for $10 \mathrm{~min}$ at $3000 \times g$, the supernatant decanted, and the pellet washed in $1 \times$ sterile phosphate-buffered saline (PBS). Pellets were then resuspended in $10 \mathrm{~mL}$ of $1 \times$ PBS. For $S$. aureus, $1 \mathrm{~mL}$ was then transferred to $9 \mathrm{~mL}$ of PBS and, for A. pittii, the tube was topped with $3 \mathrm{~mL}$ of PBS. The biomass of the cultures was measured with DENSICHEK ${ }^{\circledR}$ (bioMérieux, Marcy-l'Étoile, France) and adjusted with PBS to reach a concentration of $10^{8} \mathrm{cfu} / \mathrm{mL}$, which was then serially diluted to $10^{6} \mathrm{cfu} / \mathrm{mL}$. $100 \mu \mathrm{L}$ of one $S$. aureus recipient strain was added to $10 \mathrm{~mL}$ of TSB and $100 \mu \mathrm{L}$ of the donor $A$. pittii was added to the same $10 \mathrm{~mL}$ tube to set up the co-cultures. After gentle mixing, the complete $10 \mathrm{~mL}$ volume containing the donor and recipient was carefully added to HARVs to avoid any bubbles. HARVs were grown under SMG (vertical position) and $1 \mathrm{G}$ (horizontal position) at $33 \mathrm{rpm}$ for $20 \mathrm{~h}$ at $37^{\circ} \mathrm{C}$.

\subsection{Isolation of Colonies after HARV Growth}

After incubation, the liquid from each HARV vessel was collected and $100 \mu \mathrm{L}$, in duplicate, was plated on MSA (selective for S. aureus) (VWR, Radnor, PA, USA), MSA $+4 \mu \mathrm{g} / \mathrm{mL}$ oxacillin sodium salt monohydrate (VWR, USA) (selective for $S$. aureus that had become resistant to oxacillin) and Leeds agar (selective for A. pittii) (VWR, USA). MSA and Leeds plates were incubated overnight at $37^{\circ} \mathrm{C}$ and MSA+ oxacillin plates were incubated for $72 \mathrm{~h}$ at $37^{\circ} \mathrm{C}$. Colonies on MSA, MSA+ oxacillin, and Leeds plates were counted, and $\mathrm{cfu} / \mathrm{mL}$ was calculated. Colonies that grew on MSA+ oxacillin plates were picked and placed in $250 \mu \mathrm{L} 1 \times \mathrm{PBS}$ and stored at $4{ }^{\circ} \mathrm{C}$ until DNA extraction. DNA was extracted using the ZymoBIOMICS DNA Microprep Kit (ZymoResearch, Irvine, CA, USA) following the manufacturer's instructions.

\subsection{Designing Primers}

Primers were designed using the A. pittii IIF1SW-P1 draft genome that we had previously published, in which bla OXA-500 gene resides on scaffold 5 and ISAba1 gene on both scaffolds 44 and 70 [21]. Primers were designed using IDT DNA PrimerQuest for genes of interest. IDT DNA OligoAnalyzer was used to ensure no hairpins and correct PCR melting temperature. NCBI BLAST was used to ensure no off-target binding sites for strains used in this study. Amplification product of the primers for bla OXA-500 and the location within the genome is shown in Figure S3A and for ISAba1, in Figure S3B in Supplementary Materials. The product size of $b l a_{\mathrm{OXA}-500}$ is $591 \mathrm{bp}$ and for ISAba1, is $390 \mathrm{bp}$.

\section{4. $P C R$}

Each $25-\mu \mathrm{L}$ reaction consisted of $12.5 \mu \mathrm{L}$ of GoTaq $^{\circledR}$ Green Master Mix (Promega, Madison, WI, USA), $1 \mu \mathrm{L}$ each of forward and reverse oligonucleotide primers (10 $\mu \mathrm{M}$ each), $5.5 \mu \mathrm{L}$ of nuclease free water (Promega, USA) and $5 \mu \mathrm{L}$ of template DNA. The following primer pairs were used:

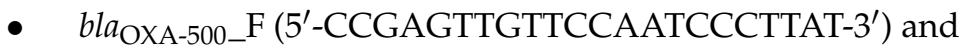

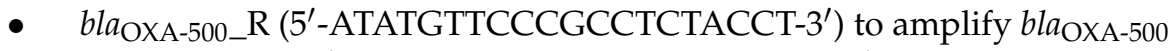

- $\quad$ and ISAba1_F (5'-ATGCAGCGCTTCTTTGCAGG-3') and

- ISAba1_R (5'-AATGATTGGTGACAATGAAG-3') to amplify ISAba1.

The reaction conditions were as follows: $95^{\circ} \mathrm{C}$ for $5 \mathrm{~min}, 35$ cycles of $95^{\circ} \mathrm{C}$ for $30 \mathrm{~s}$, $55^{\circ} \mathrm{C}$ for $30 \mathrm{~s}, 72{ }^{\circ} \mathrm{C}$ for $1 \mathrm{~min}$ and then a final extension of $72{ }^{\circ} \mathrm{C}$ for $5 \mathrm{~min}$. Amplified PCR products were run on the E-Gel ${ }^{\mathrm{TM}}$ Power Snap Electrophoresis System (Thermo Fischer, Waltham, MA, USA, cat \# G8300) using their pre-cast 1.2\% SYBR Safe, E-gels (cat \# G521801). Gels were run with a $1 \mathrm{~Kb}$ plus DNA ladder (cat \# 10488090). Gel images were captured with the built-in camera. The positive control consisted of DNA isolated from the parental A. pittii strain and the negative controls were DNA isolated from the parental S. aureus 
strains. A no-template control (NTC) consisting of molecular-grade water instead of DNA was used.

For PCR reactions that were negative, a follow-up PCR was performed using the $16 \mathrm{~S}$ rRNA gene to confirm that the DNA extraction procedure produced sufficient DNA. The following primers were used for 16S rRNA gene amplification: the forward primer, $27 \mathrm{~F}$ (5'-AGA GTT TGA TCC TGG CTC AG-3') and the reverse primer, 1492R (5'-GGT TAC CTT GTT ACG ACT T- $3^{\prime}$ ). The PCR conditions were as follows: denaturation at $95{ }^{\circ} \mathrm{C}$ for $5 \mathrm{~min}$, followed by 35 cycles consisting of denaturation at $95{ }^{\circ} \mathrm{C}$ for $50 \mathrm{~s}$, annealing at $55{ }^{\circ} \mathrm{C}$ for $50 \mathrm{~s}$, and extension at $72{ }^{\circ} \mathrm{C}$ for $1 \mathrm{~min} 30 \mathrm{~s}$ and finalized by extension at $72{ }^{\circ} \mathrm{C}$ for 10 min. PCR with the 16S rRNA gene showed that all our samples did indeed have the DNA product and that extraction was successful.

\subsection{Calculating the Efficiency of Gene Transfer}

The number of colonies that had grown on MSA+ oxacillin and were positive for at least one gene (bla $a_{\mathrm{OXA}-500}$ or ISAba1) was divided by $0.1 \mathrm{~mL}$ (the volume of the HARV culture used for plating). This number represents the theoretical concentration ( $\mathrm{cfu} / \mathrm{mL})$ of cells in the culture that have acquired one of the genes. This number was then divided by the total concentration of $S$. aureus cells $(\mathrm{cfu} / \mathrm{mL})$ in the culture, which was calculated from the number of colonies that grew on MSA.

\subsection{Chromosome vs. Plasmid Location of bla OXA-500}

Others have documented in the literature that bla $a_{\mathrm{OXA}-500}$ is located on the chromosome and is not a plasmid. To confirm that the same was true for our donor strain, A. pittii IIF1SW-P1, the following analyses were performed. plasmidSPAdes was used to assemble plasmid sequences from the whole genome-sequencing data of our strain. A simple blastn comparison between the bla $a_{\text {OXA-500 }}$ sequence and the plasmid sequences showed the absence of the gene from the plasmid-assembled contigs. Furthermore, oriTfinder was used to determine whether scaffold_5 (length $=172 \mathrm{~kb})$, on which bla OXA-500 was found, as well as the assembled sequences not characterized as plasmid sequences (from the plasmidSPAdes output above), contained evidence of plasmid markers, such as an origin of transfer site (oriT) and relaxases. None of these plasmid markers were detected on scaffold_5 and the "chromosomal" sequences.

\section{Results}

In order to determine whether HGT occurred between donor and recipient, suitable PCR primers were designed to amplify regions of the bla $a_{\mathrm{OXA}-500}$ and ISAba1 genes from A. pittii IIF1SW-P1. The sequences of the two genes, used to design the primers, were extracted from the draft whole-genome sequence of $A$. pittii IIF1SW-P1 [21]. PCR analysis performed on DNA isolated from $A$. pittii IIF1SW-P1 using the designed bla $a_{\mathrm{OXA}-500}$ and ISAba1 primers showed strong bands on an agarose gel, while PCR analysis performed on DNA isolated from the four $S$. aureus strains showed no amplicons.

To compare HGT potential between SMG and 1G, co-cultures of $A$. pittii (donor strain) and $S$. aureus (recipient strain) were grown in the HARV under SMG (vertical rotation) or $1 \mathrm{G}$ (horizontal rotation) for $20 \mathrm{~h}$, after which the culture was plated on mannitol salt agar (MSA) to select for $S$. aureus. The MSA was also supplemented with oxacillin to select only those $S$. aureus colonies that had acquired resistance to the antibiotic. To verify that this newly acquired resistance to oxacillin was not due to spontaneous mutations but rather through the HGT of bla $a_{\mathrm{OXA}-500}$ and ISAba1 from $A$. pittii, the S. aureus colonies that grew on MSA supplemented with oxacillin were picked for PCR analysis. A schematic of the experimental set-up is shown in Figure 1. 

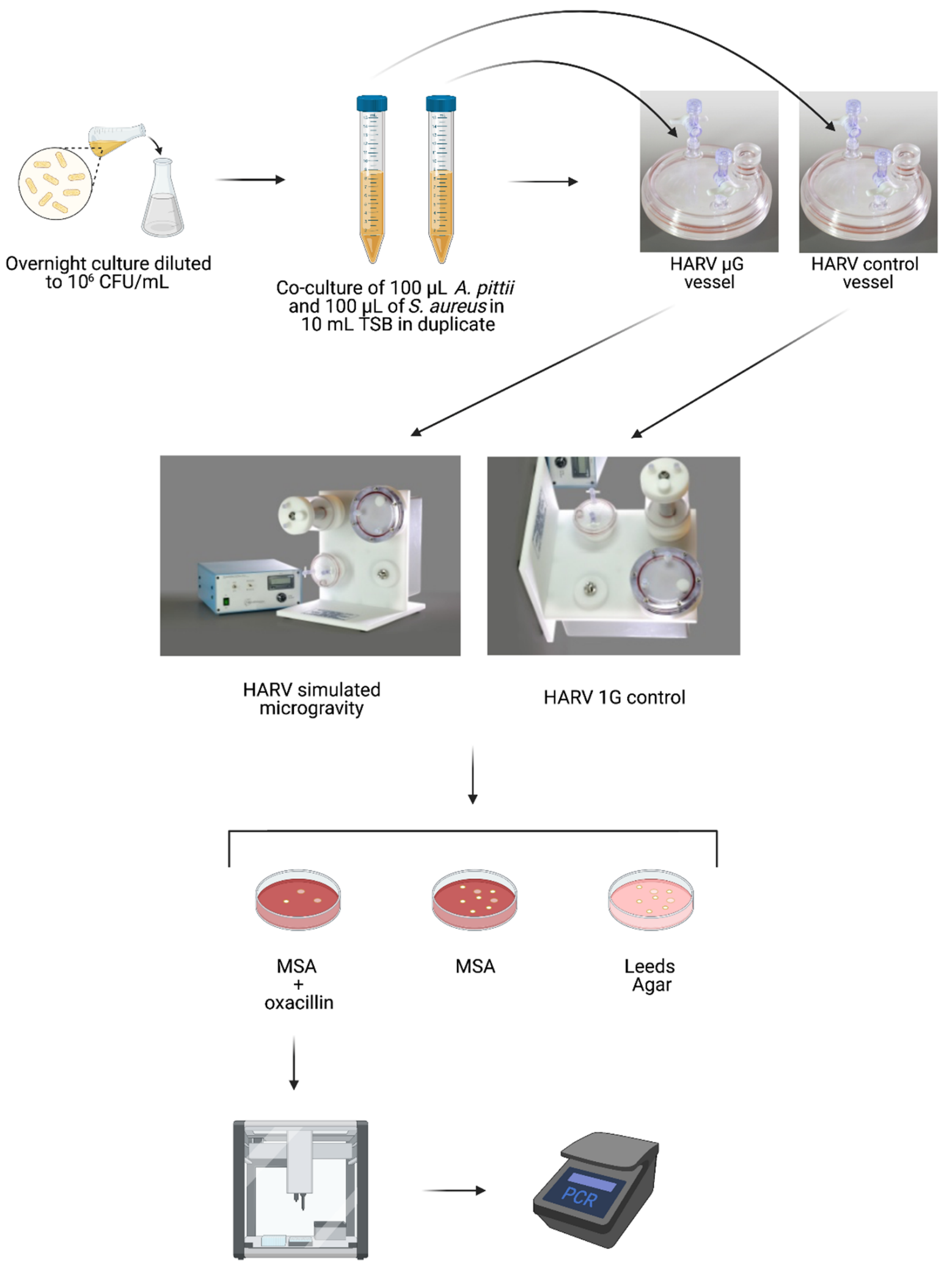

DNA Extraction

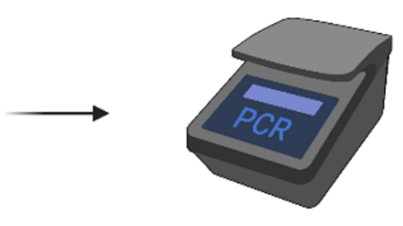

PCR for

$b / a_{0 \times A-500}$ and ISAba 1

Figure 1. Schematic of experimental protocol.

Figure 2 shows the proportion of colonies that grew on MSA supplemented with oxacillin that were positive for bla OXA-500 (Figure 2A), ISAba1 (Figure 2B) and both (Figure 2C). Rep- 
resentative gel images are shown in Figure S1. On average, 77\% of the S. aureus colonies that were grown with $A$. pittii under SMG and had acquired resistance to oxacillin now harbored both $b l a_{\mathrm{OXA}}-500$ and ISAbal ( $89 \%$ of the colonies had acquired at least one). This is in contrast with $1 \mathrm{G}$, where only $1 \%$ of $S$. aureus colonies that had acquired oxacillin resistance were positive for both bla $a_{\mathrm{OXA}-500}$ and ISAba1 ( $8 \%$ of the colonies had acquired at least one).

$\mathbf{A}$

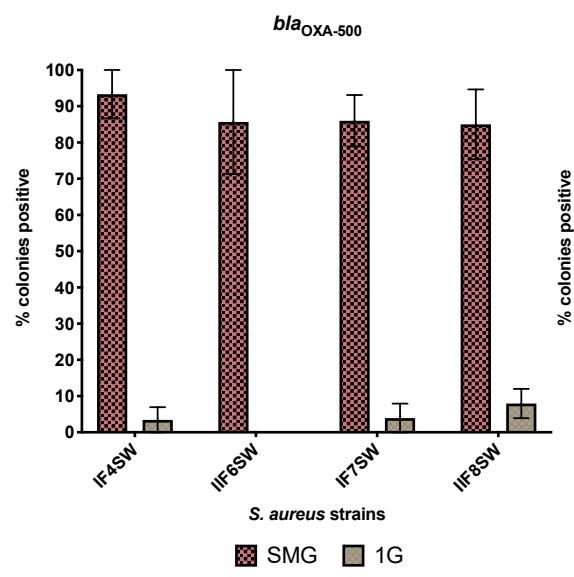

B

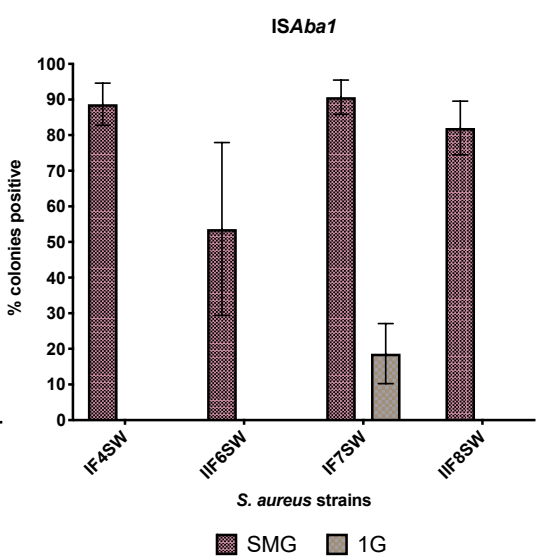

C

Figure 2. Comparison of HGT activity between SMG and 1G. Four strains of S. aureus (IF4SW, IIF6SW, IF7SW, IIF8SW) were used as the recipient and were co-cultured (separately) with the donor strain A. pittii for $20 \mathrm{~h}$ at $37^{\circ} \mathrm{C}$ under SMG or $1 \mathrm{G}$ conditions. Cultures were plated on MSA containing $4 \mu \mathrm{g} / \mathrm{mL}$ of oxacillin. Colonies that grew were picked, subjected to DNA extraction and then analyzed by PCR with primers specific to $b l a_{\mathrm{OXA}-500}$ and ISAbaI from the donor strain. The graphs show the percent of $S$. aureus colonies, from each strain, that grew on MSA+ oxacillin that had acquired (A) bla OXA-500, (B) ISAba1 or (C) both genes from the donor A. pittii.

The differences in proportions observed between SMG and $1 G$ were not due to differences in growth at these different conditions, as each strain showed the same biomass after $20 \mathrm{~h}$, whether grown under SMG or $1 \mathrm{G}$ (Figure S2).

The efficiency of transfer under SMG for all four strains was, on average, $3.06 \times 10^{-7}$ while, for $1 \mathrm{G}$, it was $3.21 \times 10^{-9}$ (Table 1 ). While all strains had similar efficiencies, IIF8SW had the highest and IIF6SW the lowest.

Table 1. Efficiency of HGT. Average values of the three biological replicates, with the range of the values shown in parentheses. Efficiency was based on colonies that at acquired at least one gene (either bla OXA-500 or ISAba1).

\begin{tabular}{ccc}
\hline S. aureus Recipient Strain & SMG (Range) & 1G (Range) \\
\hline IF4SW & $4.21 \times 10^{-7}\left(1.1 \times 10^{-6}\right.$ to $\left.5.2 \times 10^{-8}\right)$ & $2.05 \times 10^{-9}\left(0.0\right.$ to $\left.4.1 \times 10^{-9}\right)$ \\
IIF6SW & $4.54 \times 10^{-8}\left(7.5 \times 10^{-8}\right.$ to $\left.6.3 \times 10^{-9}\right)$ & $0.0($ no transfer $)$ \\
IF7SW & $3.20 \times 10^{-7}\left(7.2 \times 10^{-7}\right.$ to $\left.9.9 \times 10^{-8}\right)$ & $4.33 \times 10^{-9}\left(7.5 \times 10^{-9}\right.$ to $\left.2.2 \times 10^{-9}\right)$ \\
IIF8SW & $4.38 \times 10^{-7}\left(6.8 \times 10^{-7}\right.$ to $\left.3.1 \times 10^{-9}\right)$ & $6.07 \times 10^{-9}\left(0.0\right.$ to $\left.1.2 \times 10^{-9}\right)$ \\
\hline
\end{tabular}

To determine how stable these donor genes were in the recipient, two resistant $S$. aureus 1F4SW colonies that had acquired both genes were sub-cultured on MSA + oxacillin plates, a total of four times. Even after the 4th sub-culture, the colonies were still resistant to oxacillin, and PCR confirmed that bla $a_{\mathrm{OXA}-500}$ and ISAba1 were still present within the genome.

\section{Discussion}

We have shown that HGT is increased under SMG compared to 1G. The transfer of AMR genes, which were tracked by PCR, occurred in the absence of selective pressure by antibiotics. This transfer led to functional changes, as the acquisition of the two AMR genes, 
$b l a_{\mathrm{OXA}-500}$ and ISAba1, that were tracked in the four strains of S. aureus, made them resistant to oxacillin, to which they were previously susceptible. These results have significant implications for long-duration space missions because pathogens that are susceptible to antibiotics could become resistant and thus harder to treat. In addition, even if astronauts are screened for problematic microbes prior to flight, issues could still arise, as commensals are known to act as reservoirs for AMR genes that can be disseminated to (opportunistic) pathogens [22-24]. For example, a study conducted in a hospital in the Netherlands showed that mec $A$ gene transfer occurred in a patient between $m e c A^{+}$S. epidermidis and a $m e c A^{-}$ strain of $S$. aureus [25].

It was beyond the scope of the study to determine the cause of the increased HGT that was observed, but one mechanism could be increased competence, allowing for transformation to occur, one of three modes of gene transfer. Competence allows bacterial cells to uptake DNA from its environment and increase the response to different stressors [26-29]. In this case, naked DNA released from dead $A$. pittii cells could have been readily taken up by $S$. aureus when exposed to SMG due to an increase in its competence. While $S$. aureus is not classically considered to be naturally competent, as Streptococcus pneumoniae and Bacillus subtilis are, it does harbor genes that are involved in competence and thought to promote natural competence under the right conditions [30,31]. The conditions that $S$. aureus needs are not yet known, but, similar to other bacteria, it could be an adverse environment. Indeed, when $S$. aureus cells were subjected to heat-shock, cold-shock and the stringent response, there was increased expression of competence gene orthologs compared to the non-stressed conditions [32]. In S. pneumoniae and B. subtilis, competence confers a survival advantage when cells are subjected to stress $[33,34]$, so there is a possibility that growth under SMG led to an adverse environment for $S$. aureus, causing cells to become more competent to increase survival. Conjugation is a less likely scenario since, consistent with what others have documented in the literature, bla $a_{\mathrm{OXA}-500}$ is located on the chromosome and not a plasmid. A second mechanism could be increased transduction caused by growth under SMG. Transduction is the transfer of genetic material via bacterial phages. It is well known that prophage activity is increased during stress, leading to increased phage production, helping the host survive these adverse conditions $[35,36]$.

\section{Conclusions}

This paper describes, for the first time, the effects of SMG on HGT and has shown that it is increased in SMG compared to 1G. If the same trend is observed on the ISS, this will have a significant impact on how we view bacterial interactions in space and its effects on astronaut health. The next steps would be to elucidate the mechanisms behind the HGT, to develop appropriate countermeasures for long-duration space missions.

Supplementary Materials: The following are available online at https: / www.mdpi.com/article/ 10.3390/life11090960/s1, Figure S1: Representative gel images of PCR analysis. Figure S2: Colony forming units of strains grown in SMG and 1G. Figure S3: Schematic of designed primers and their location within the donor genome.

Author Contributions: C.U. conceptualized the study, designed the primers, performed all experiments, analyzed the data, and wrote the manuscript. T.G. helped design the primers and optimize the initial protocol. C.E.M. provides ongoing whole genome sequencing capabilities for the lab. K.V. provided guidance during concept maturation, critically reviewed the data and the manuscript. All authors have read and agreed to the published version of the manuscript.

Funding: This study was funded by the National Aeronautics and Space Administration 2020 Space Biology (NNH18ZTT001N-FG2) grant (80NSSC21K0320) awarded to CU and a 2012 Space Biology NNH12ZTT001N Grant No. 19-12829-26 under Task Order NNN13D111T awarded to KV.

Institutional Review Board Statement: Not applicable.

Informed Consent Statement: Not applicable. 
Data Availability Statement: The draft genomes of the parental strains used for the co-cultures can be found in NCBI under accession number MIZX00000000, MIZH00000000, MIZN00000000, MIZM00000000, MIZP00000000 and are presented in the manuscript by Checinska Sielaff A et al. [21].

Conflicts of Interest: The authors declare no conflict of interest.

\section{References}

1. Schulze-Makuch, D.; Wagner, D.; Kounaves, S.P.; Mangelsdorf, K.; Devine, K.G.; de Vera, J.-P.; Schmitt-Kopplin, P.; Grossart, H.-P.; Parro, V.; Kaupenjohann, M.; et al. Transitory microbial habitat in the hyperarid Atacama Desert. Proc. Natl. Acad. Sci. USA 2018, 115, 2670-2675. [CrossRef]

2. Carpa, R.; Keul, A.; Muntean, V.; Dobrotă, C. Characterization of halophilic bacterial communities in Turda Salt Mine (Romania). Orig. Life Evol. Biosph. 2014, 44, 223-230. [CrossRef]

3. Humayoun, S.B.; Bano, N.; Hollibaugh, J.T. Depth distribution of microbial diversity in Mono Lake, a meromictic soda lake in California. Appl. Environ. Microbiol. 2003, 69, 1030-1042. [CrossRef]

4. Walker, J.J.; Spear, J.R.; Pace, N.R. Geobiology of a microbial endolithic community in the Yellowstone geothermal environment. Nature 2005, 434, 1011-1014. [CrossRef] [PubMed]

5. Ji, M.; Greening, C.; Vanwonterghem, I.; Carere, C.R.; Bay, S.K.; Steen, J.A.; Montgomery, K.; Lines, T.; Beardall, J.; van Dorst, J.; et al. Atmospheric trace gases support primary production in Antarctic desert surface soil. Nature 2017, 552, 400. [CrossRef]

6. Yamaguchi, N.; Roberts, M.; Castro, S.; Oubre, C.; Makimura, K.; Leys, N.; Grohmann, E.; Sugita, T.; Ichijo, T.; Nasu, M. Microbial monitoring of crewed habitats in space-current status and future perspectives. Microb. Environ. 2014, 29, 250-260. [CrossRef] [PubMed]

7. Urbaniak, C.; Sielaff, A.C.; Frey, K.G.; Allen, J.E.; Singh, N.; Jaing, C.; Wheeler, K.; Venkateswaran, K. Detection of antimicrobial resistance genes associated with the International Space Station environmental surfaces. Sci. Rep. 2018, 8, 814. [CrossRef] [PubMed]

8. Checinska Sielaff, A.; Urbaniak, C.; Mohan, G.B.M.; Stepanov, V.G.; Tran, Q.; Wood, J.M.; Minich, J.; McDonald, D.; Mayer, T.; Knight, R.; et al. Characterization of the total and viable bacterial and fungal communities associated with the International Space Station surfaces. Microbiome 2019, 7, 50. [CrossRef]

9. Singh, N.K.; Wood, J.M.; Karouia, F.; Venkateswaran, K. Succession and persistence of microbial communities and antimicrobial resistance genes associated with International Space Station environmental surfaces. Microbiome 2018, 6, 204. [CrossRef] [PubMed]

10. Soucy, S.M.; Huang, J.; Gogarten, J.P. Horizontal gene transfer: Building the web of life. Nat. Rev. Genet. 2015, 16, 472-482. [CrossRef]

11. Frost, L.S.; Leplae, R.; Summers, A.O.; Toussaint, A. Mobile genetic elements: The agents of open source evolution. Nat. Rev. Microbiol. 2005, 3, 722-732. [CrossRef]

12. Roberts, A.P.; Kreth, J. The impact of horizontal gene transfer on the adaptive ability of the human oral microbiome. Front. Cell. Infect. Microbiol. 2014, 4, 124. [CrossRef] [PubMed]

13. Webster, N.S.; Reusch, T.B.H. Microbial contributions to the persistence of coral reefs. ISME J. 2017, 11, 2167. [CrossRef] [PubMed]

14. Koonin, E.V.; Makarova, K.S.; Aravind, L. Horizontal gene transfer in prokaryotes: Quantification and classification. Annu. Rev. Microbiol. 2001, 55, 709-742. [CrossRef] [PubMed]

15. Brooks, A.N.; Turkarslan, S.; Beer, K.D.; Lo, F.Y.; Baliga, N.S. Adaptation of cells to new environments. Wiley Interdiscip. Rev. Syst. Biol. Med. 2011, 3, 544-561. [CrossRef] [PubMed]

16. Vogan, A.A.; Higgs, P.G. The advantages and disadvantages of horizontal gene transfer and the emergence of the first species. Biol. Direct 2011, 6, 1. [CrossRef]

17. Schiwon, K.; Arends, K.; Rogowski, K.M.; Fürch, S.; Prescha, K.; Sakinc, T.; Van Houdt, R.; Werner, G.; Grohmann, E. Comparison of antibiotic resistance, biofilm formation and conjugative transfer of Staphylococcus and Enterococcus isolates from International Space Station and Antarctic Research Station Concordia. Microb. Ecol. 2013, 65, 638-651. [CrossRef]

18. Evans, B.A.; Amyes, S.G.B. OXA $\beta$-lactamases. Clin. Microbiol. Rev. 2014, 27, 241-263. [CrossRef]

19. Khurshid, M.; Rasool, M.H.; Ashfaq, U.A.; Aslam, B.; Waseem, M. Emergence of ISAba1 harboring carbapenem-resistant Acinetobacter baumannii isolates in Pakistan. Future Microbiol. 2017, 12, 1261-1269. [CrossRef]

20. Mugnier, P.D.; Poirel, L.; Nordmann, P. Functional analysis of insertion sequence ISAba1, responsible for genomic plasticity of Acinetobacter baumannii. J. Bacteriol. 2009, 191, 2414-2418. [CrossRef]

21. Checinska Sielaff, A.; Singh, N.K.; Allen, J.E.; Thissen, J.; Jaing, C.; Venkateswaran, K. Draft Genome Sequences of Biosafety Level 2 Opportunistic Pathogens Isolated from the Environmental Surfaces of the International Space Station. Genome Announc. 2016, 4, e01263-e01316. [CrossRef] [PubMed]

22. Brinkac, L.; Voorhies, A.; Gomez, A.; Nelson, K.E. The Threat of Antimicrobial Resistance on the Human Microbiome. Microb. Ecol. 2017, 74, 1001-1008. [CrossRef] [PubMed]

23. Penders, J.; Stobberingh, E.E.; Savelkoul, P.H.M.; Wolffs, P.F.G. The human microbiome as a reservoir of antimicrobial resistance. Front. Microbiol. 2013, 4, 87. [CrossRef] [PubMed]

24. Huddleston, J.R. Horizontal gene transfer in the human gastrointestinal tract: Potential spread of antibiotic resistance genes. Infect. Drug Resist. 2014, 7, 167-176. [CrossRef] [PubMed] 
25. Wielders, C.L.C.; Vriens, M.R.; Brisse, S.; de Graaf-Miltenburg, L.A.M.; Troelstra, A.; Fleer, A.; Schmitz, F.J.; Verhoef, J.; Fluit, A.C. Evidence for in-vivo transfer of mecA DNA between strains of Staphylococcus aureus. Lancet 2001, 357, 1674-1675. [CrossRef]

26. Charpentier, X.; Kay, E.; Schneider, D.; Shuman, H.A. Antibiotics and UV Radiation Induce Competence for Natural Transformation in Legionella pneumophila. J. Bacteriol. 2011, 193, 1114-1121. [CrossRef] [PubMed]

27. Claverys, J.-P.; Prudhomme, M.; Martin, B. Induction of Competence Regulons as a General Response to Stress in Gram-Positive Bacteria. Annu. Rev. Microbiol. 2006, 60, 451-475. [CrossRef]

28. Manna, S.; Waring, A.; Papanicolaou, A.; Hall, N.E.; Bozinovski, S.; Dunne, E.M.; Satzke, C. The transcriptomic response of Streptococcus pneumoniae following exposure to cigarette smoke extract. Sci. Rep. 2018, 8, 15716. [CrossRef]

29. Slager, J.; Kjos, M.; Attaiech, L.; Veening, J.W. Antibiotic-induced replication stress triggers bacterial competence by increasing gene dosage near the origin. Cell 2014, 157, 395-406. [CrossRef]

30. Fagerlund, A.; Granum, P.E.; Håvarstein, L.S. Staphylococcus aureus competence genes: Mapping of the SigH, ComK1 and ComK2 regulons by transcriptome sequencing. Mol. Microbiol. 2014, 94, 557-579. [CrossRef]

31. Morikawa, K.; Takemura, A.J.; Inose, Y.; Tsai, M.; Nguyen Thi le, T.; Ohta, T.; Msadek, T. Expression of a cryptic secondary sigma factor gene unveils natural competence for DNA transformation in Staphylococcus aureus. PLoS Pathog. 2012, 8, e1003003. [CrossRef] [PubMed]

32. Anderson, K.L.; Roberts, C.; Disz, T.; Vonstein, V.; Hwang, K.; Overbeek, R.; Olson, P.D.; Projan, S.J.; Dunman, P.M. Characterization of the Staphylococcus aureus heat shock, cold shock, stringent, and SOS responses and their effects on log-phase mRNA turnover. J. Bacteriol. 2006, 188, 6739-6756. [CrossRef] [PubMed]

33. Engelmoer, D.J.; Rozen, D.E. Competence increases survival during stress in Streptococcus pneumoniae. Evol. Int. J. Org. Evol. 2011, 65, 3475-3485. [CrossRef] [PubMed]

34. Schultz, D.; Wolynes, P.G.; Jacob, E.B.; Onuchic, J.N. Deciding fate in adverse times: Sporulation and competence in Bacillus subtilis. Proc. Natl. Acad. Sci. USA 2009, 106, 21027-21034. [CrossRef] [PubMed]

35. Wang, X.; Kim, Y.; Ma, Q.; Hong, S.H.; Pokusaeva, K.; Sturino, J.M.; Wood, T.K. Cryptic prophages help bacteria cope with adverse environments. Nat. Commun. 2010, 1, 147. [CrossRef] [PubMed]

36. Du Toit, A. Phage induction in different contexts. Nat. Rev. Microbiol. 2019, 17, 126-127. [CrossRef] 